\title{
Predicting police officer seat belt use: Evidence-based solutions to improve officer driving safety
}

Paper forthcoming in Police Quarterly

Scott Wolfe

School of Criminal Justice

Michigan State University 655 Auditorium Dr. Baker Hall, Room 510

East Lansing, MI 48824

Phone: (517) 432-7160

email:wolfesc1@msu.edu

Spencer G. Lawson

School of Criminal Justice

Michigan State University 655 Auditorium Dr.

Baker Hall

East Lansing, MI 48824

lawsonsp@msu.edu

Jeff Rojek

School of Criminal Justice

Michigan State University

655 Auditorium Dr.

Baker Hall

East Lansing, MI 48824

rojekjef@msu.edu

Geoffrey Alpert

Department of Criminology and Criminal Justice

University of South Carolina

1305 Greene St.

Currell College, Room 202

Columbia, SC 29208

Phone: (803) 777-6424

email: GEOFFA@mailbox.sc.edu

and

Griffith University Brisbane, Australia

* This research was funded by the Bureau of Justice Assistance, Office of Justice Programs, US Department of Justice (2012-DB-BX-K002). Points of view and opinions provided are those of the authors and do not necessarily represent the official position of the US Department of Justice. Please address all correspondence to Scott Wolfe, Michigan State University, School of Criminal Justice, 510 Baker Hall, East Lansing, MI 48824. email: wolfesc1@msu.edu. Phone: (517) 4327160 . 


\title{
Predicting police officer seat belt use: Evidence-based solutions to improve officer driving safety
}

\begin{abstract}
One of the hidden dangers of police work is self-imposed - the failure to wear seat belts. Unfortunately, little evidence exists concerning the factors that account for why officers do not wear their seat belts. This study used a sample of 450 police officers to develop and test a framework for understanding the predictors of seat belt use. We found several factors were associated with the frequency of officer seat belt use: the perceived likelihood of supervisors enforcing seat belt and other driving policies, organizational justice, having a departmental colleague previously struck by a vehicle, law enforcement experience, risky driving attitudes, number of prior on-duty collisions, being a patrol officer vs. supervisor, and perceived risk of being involved in a vehicle collision. We discuss the practical implications of these findings as they apply to efforts aimed at improving officer driving safety and subsequent reduction in related injuries and deaths.
\end{abstract}

Keywords: officer-involved vehicle collisions, traffic crashes, seat belt use, officer safety and wellness 


\section{Predicting police officer seat belt use: Evidence-based solutions to improve officer driving safety}

Over the years a lot has been written on the dangers of policing. Most of the work focuses on suspects resisting officers and even attacking or using deadly force against them. A hidden danger is self-imposed - the failure to wear seat belts. Officer-involved vehicle collisions are a leading cause of frontline officer injuries and fatalities (Tiesman et al., 2019), and failure to wear a seat belt is one of the main causes of such casualties (LaTourette, 2015; Noh, 2011; Tiesman, et al., 2016; Wolfe et al., 2015). To date, however, we have little evidence concerning why officers choose not to wear their seat belts. This leaves a void in police managers' ability to adopt evidencebased solutions to improve officer driving safety.

Wehr, Alpert, and Rojek’s (2012; see also Wehr, 2015) analysis based on around 100 qualitative interviews with California officers represents the best effort to date. They found that officers neglected to wear a seat belt primarily because of the fear of an ambush—what they referred to as fear of the "ninja assassin" (a seat belt would inhibit escape)—and comfort issues (see also, Oron-Gilad et al., 2005). Also, we have examples of initiatives that have targeted policy and enforcement changes regarding seat belt use to help reduce injuries and deaths resulting from officer-involved collisions (Destination Zero, n.d.; Tiesman, et al., 2019). Yet, interventions that target non-usage of seat belts are developed with limited understanding of why officers chose not to wear them.

Accordingly, the purpose of this study is two-fold. First, we discuss the likely factors associated with seat belt use based on prior injury-prevention and traffic-safety research, and the small, but growing literature on police vehicle collisions. The goal of this effort is to formulate a framework for understanding the factors that predict officer seat belt use. Second, we will test the extent to which the identified factors are associated with reported seat belt use among a sample of 
450 police officers. The overarching goal of this study is to increase our understanding of the factors associated with officer seat belt use which will allow us to be more deliberate when attempting to implement evidence-based strategies geared toward reducing officer injuries and fatalities from collisions.

\section{Officer-Involved Vehicle Collisions and Seat Belt Use}

Patrol duty is generally viewed as one of the more dangerous assignments for officers (Barker, 1999). While patrol officers are expected to deal with unpredictability during citizen interactions, they are already at-risk for injury or death well before they even step out of their patrol vehicles. Patrol officers are exposed to many dangerous conditions while on the roadway (e.g., vehicle pursuits, traffic stops, and traffic management), increasing the likelihood of them becoming involved in traffic collisions (Langham, Hole, Edwards, \& O’Neil, 2002). Due to the inherent danger of driving, distractions officers encounter within their patrol vehicles, and prolonged driving times, officer-involved vehicle collisions have remained a leading cause of death for law enforcement officers (NLEOMF, n.d.). Forty-six officers were killed in 2017 and 49 were killed in 2018 in traffic-related incidents making it a leading cause of death to officers in those years (Noh, 2011; NLEOMF, n.d.; James, 2015; Tiesman \& Heick, 2014). In 2019, 128 officers were killed while on duty, 43 of whom were involved in traffic-related fatalities. An even larger number of officers injured in vehicle collisions annually face considerable financial, physical, and emotional consequences. One study found that for every officer killed in a collision there were 234 officers injured (Wolfe et al., 2015). Additionally, families, friends, and departments are beset with immeasurable costs when officers are killed or injured in vehicle collisions. 
Seat belt use (or lack thereof) is a significant area of concern within policing. When properly used, seat belts can increase a vehicle occupant's chance of surviving a potentially fatal collision from 44 percent to 73 percent (Blincoe et al., 2014). In 2018, the national rate for seat belt usage among the general driving public was about 90 percent (NCSA, 2019). In contrast, a study conducted by the National Highway Traffic Safety Administration (2011) found that of the 733 police officers who died in passenger vehicle collisions between 1980 and 2008, only 45 percent had their seat belt properly fastened. It short, it is common for police officers to neglect seat belt use and this decision directly causes more officer injuries and deaths.

Law enforcement agencies attempt to emphasize safe driving practices to reduce or prevent fatal and non-fatal injuries from vehicle collisions. For example, Below 100 (www.below100.org) and Destination Zero (www.destinationzero.org) are national-level initiatives that bring awareness to officer safety through training and education campaigns and both programs focus considerable attention on increasing seat belt use. The Prince George’s County (MD) Police Department started the "Arrive Alive" education campaign to reduce and prevent the deleterious outcomes resulting from officer-involved vehicle collisions after several of their officers died in collisions in a short period of time. The department identified seat belt non-usage, excessive speeding, and distracted driving as the leading causes of officer-involved collision deaths and serious injuries. To mitigate these critical collision factors, the department promoted safe driving practices by instituting daily safety messages delivered by command staff which were broadcasted over its police radio. Messages reminded patrol officers to adhere to the department's mandatory seat belt usage policy, to slow down while driving, and to minimize technological distractions (Hansen, 2015; Stawinski, 2014). 
Despite the expanding implementation of traffic safety programs aimed at reducing the occurrence and severity of officer-involved collisions, the law enforcement community lacks independent empirical evaluations of those programs. Most of what is known has been generated from descriptions of program models and self-reported results found on publicly available policerelated sources (e.g., COPS Office, Destination Zero). Considering this important knowledge gap, Tiesman and colleagues (2019) conducted the first empirical evaluation of an officer-involved vehicle collision prevention program. The Las Vegas Metropolitan Police Department (LVMPD) experienced three officer fatalities resulting from on-duty motor-vehicle crashes within a sixmonth period. In response, the department launched a three-pronged initiative to reduce and prevent officer-involved vehicle collisions: changes in driving policy and procedure, utilization of an education campaign, and modifications to its driver training. Tiesman and colleagues found that LVMPD's crash prevention program was associated with reductions in crash and injury rates during the post-intervention period. Fewer motor-vehicle crashes and related injuries were not observed in two control agencies that did not implement a crash prevention program. Furthermore, officer seat belt usage increased significantly between pre-intervention (87\%) and postintervention (97\%) among officers involved in collisions. Traffic safety initiatives of this type are taking steps in the right direction regarding improving officer driving safety. Yet, such efforts are not guided by an understanding of the factors that predict why officers decide not to wear a seat belt while driving on duty.

\section{An Organizing Theoretical Framework for Understanding Officer Seat Belt Use}

Understanding officer behavior of any kind is a complex endeavor. Take, for example, police use of force. An officer's decision to use force against a civilian is predicted by factors such as individual officer characteristics (Alpert, 1989; Sherman \& Blumberg, 1981), citizen demeanor 
(Garner, Maxwell, \& Heraux, 2002; McCluskey \& Terrill, 2005; Nix, Pickett, Wolfe, \& Campbell, 2017; Weisburd, Greenspan, Hamilton, Williams, \& Bryant, 2000), patrol neighborhood characteristics (Lee, Vaughn, \& Lim, 2014; Shjarback, 2018; Smith, 1986; Terrill \& Reisig, 2003), and organizational characteristics like supervisor treatment, departmental policy, and culture (Alpert \& Rojek, 2011; Ingram, Terrill, \& Paoline, 2018; Wolfe \& Piquero, 2011).

Officer involvement in on-duty traffic crashes is predicted by a similar set of complex factors. Sleep deprivation among officers degrades officer performance and leads to officerinvolved collisions (Vila 2006; Vila 2009; James \& Vila, 2015). Age, gender, and experience also play a critical role in on-duty traffic crashes (NTSA, 2019). Data from the Fatality Analysis Reporting System (FARS) between 1980 and 2008 indicated that the occurrence of officerinvolved traffic crashes is higher during dark hours (8 p.m. to 4:59 a.m.) and in urban areas (NTSA, 2019). Moreover, the range of technologies integrated into the interior design of patrol vehicles may overwhelm and distract officers, which can exacerbate risky driving behaviors and hamper basic driving skills (James, 2015). A lack of advanced driver training also increases officers’ risk for on-duty crashes (NHTSA, 2019).

More research attention needs to be devoted toward the factors associated with officers deciding to wear or not wear a seat belt while driving on-duty. Based on our review of the general traffic collision and officer-involved collision literatures, we have identified six domains that are

theoretically salient to seat belt use. The predictors center on individual characteristics, impulsive attitudes, risky behaviors, training experiences, agency policies, and organizational factors.

\section{Officer Characteristics}

Gender is one of the strongest predictors of a host of risky attitudes and behaviors. The gender-gap observed in criminology is a good example—all else equal, men commit more criminal 
behavior than women (Lauritsen, Heimer, \& Lynch, 2009). Psychological research suggests that, on average, males are less risk-averse and tend to engage in riskier activities than females (Wilson \& Daly, 1985). This observation also has been found in the traffic collision literature. On the one hand, Lewis and colleagues (2007) found that females were more likely than males to report that fear-invoking advertisements (e.g., messages warning about the dangers of speeding or drunk driving) would impact their own driving behavior. On the other hand, males were more likely to indicate that such advertisements would have a greater impact on others than themselves (i.e., the third-person effect). Exposure to the advertisements also led female drivers to be less inclined to speed or drive drunk compared to males. The collision literature also reveals that male drivers are more likely than females to be injured and killed in traffic collisions (Tay, 2002, 2005). In this way, we expect officer gender to impact seat belt use. Male officers may be more inclined to take driving-related risks than their female counterparts and choose to wear a seat belt less frequently. We also expect younger officers to report less frequent seat belt use and more experienced officers to wear a seat belt more often (Tay, 2002, 2005). Wehr's (2015) interview data supported the argument that officers become more risk averse on the job as they gain more experience. Furthermore, the broader collision literature shows that education serves as protective factors against crash involvement (Romano, Tippetts, \& Voas, 2006). Thus, we expect officers with higher levels of education to report more frequent seat belt use.

Beyond demographic characteristics, criminological research has a long history of demonstrating the importance of individual social relationships as inhibitors to risky attitudes and behaviors. Being in a committed relationship and having children, for example, act as informal social control mechanisms on peoples' behavior and result in less criminal activity (Sampson \& Laub, 1995; Laub \& Sampson, 2003). In a similar way, we expect seat belt use to be associated 
with such social control factors. Officers with a committed partner or children at home have greater stakes in conformity (Toby, 1957) and are expected to make driving-related decisions with their own safety in mind.

\section{Officer Safety Risk Perceptions}

Perceptions of driving-related risks also may be important predictors of seat belt use. Drivers that perceive the risk of traffic collisions to be low are much more likely to engage in risky driving behaviors and be involved in collisions (Elander, West, \& French, 1993; Finn \& Bragg, 1986; Lund \& Rundmo, 2009; Nordfjærn, Jørgensen, \& Rundmo, 2011; Ullegerg \& Rundmo, 2003). Consistent with this literature, we expect officers that perceive a higher risk of being involved in a traffic collision while driving on-duty to report more frequent seat belt use, and seat belt use to be less frequent among officers who do not believe collision risk is high. Relatedly, because police activity almost always involves driving, officers' perceptions regarding the overall risks of emergency and regular patrol driving likely impact seat belt use. Whereas officers who believe emergency driving is risky likely wear their seat belts more often, those who believe regular patrol driving to be safe are less likely to wear their seat belts.

At the same time, however, policing involves other serious risks such as being assaulted or shot while on-duty. We argue that officers' general perceptions of risk may impact the way they behave in all aspects of their jobs. On average, officers that perceive the risk of being assaulted or shot to be higher are likely to adjust behavior accordingly. In the mind of many officers, seat belts inhibit movement and may prevent them from seeking cover if they are ambushed while in their car. Based on the available evidence and consistent with the Wehr and colleague's (2012; Wehr, 2015) “ninja assassin” hypothesis, we anticipate officers that believe there is a high risk of being assaulted or shot while on the job to be less likely to wear their seat belts. Considering the role of 
general risk perceptions also allows us to consider its impact on seat belt use compared to the previously mentioned driving-specific perceptions.

\section{Risky Driving Attitudes and Activity}

Risky attitudes are predictive of risky behaviors. In the broader psychological and criminological literatures, for example, low self-control often emerges as a key predictor of risky behaviors (Gottfredson \& Hirschi, 1990; Malouf et al., 2014; Pratt \& Cullen, 2000; Pratt et al., 2014). Low self-control is a multifaceted personality construct typically conceptualized by impulsive, undisciplined, and unhealthy behavior (Reisig, Wolfe, \& Pratt, 2012; Tangney et al., 2004). Attitudes and behaviors that are characterized as risky, impulsive, and short-sighted have been shown to be some of strongest predictors of collisions involvement and dangerous driving behavior among the general public (Clarke \& Robertson, 2005; Dahlen et al., 2005; de Winter \& Dodou, 2010; Elander et al., 1993; Ellwanger \& Pratt, 2012; Parker et al., 1995; Sümer, 2003). Within a police context, we expect less frequent seat belt use among officers with greater preference or tolerance for other risky behaviors (e.g., believing it is fun to drive fast while onduty or that officers must take driving-related risks to be good cops).

One of the best ways to capture individual levels of self-control is to measure behavioral tendencies (Hirschi \& Gottfredson, 1993; Wolfe \& Hoffmann, 2016). Thus, while risky attitudes are likely important, actual risky driving behaviors also may play a role in predicting officer seat belt use. Distracted driving has been identified as an important correlate of traffic crash involvement. For example, the risk of a collision is much higher when drivers use a cell phone while driving (i.e., dial or text) (Farmer et al., 2015; Klauer et al., 2014; Redelmeier and Tibshirani, 1997). Accordingly, using a cell phone or texting while driving on-duty are risky behaviors that likely are correlated with other risky activities such as lack of seat belt use. 
Relatedly, off-duty driving behavior may be associated with on-duty driving behavior (Newman, Griffin, \& Mason, 2008; Newman, Watson, \& Murray, 2002; 2004). Officers who have been involved in off-duty traffic collisions or been pulled over for a traffic violation, on average, may be engaging in riskier driving activities overall which should predict less frequent seat belt use while on-duty. In a similar way, on-duty collision involvement, regardless of seriousness, is likely a proxy for risky driving activity (all else equal). We expect officers with more on-duty collision experience to report less frequent seat belt use.

Police research has a long history of examining subcultural orientations in efforts to understand officer behavior (Ingram, Paoline, \& Terrill, 2013; Paoline, 2003; Pickett \& Nix, 2019). Aggressive enforcement orientations, for example, have been shown to predict more frequent use of force (Terrill, Paoline, \& Manning, 2003). Conversely, officers with more of an order maintenance orientation toward their jobs tend to use force less frequently. In this way, an aggressive enforcement orientation should expose officers to additional risky behaviors such as not wearing a seat belt. Officers that adhere to an order maintenance style of policing, however, may engender additional risk reduction behaviors such as wearing a seat belt while on patrol.

\section{Training Experiences}

Law enforcement officers are given a specified amount time dedicated to academy and inservice training as mandated by state standards and department policy. Unfortunately, most training time is dedicated to firearms instruction and use of force (Wolfe, Rojek, McLean, \& Alpert, 2020). Much less training is devoted toward driving-related decision making. Officers who have experienced more driving-related training (e.g., driver decision-making, EVOC, pursuit, and simulator training) are likely better and safer drivers than those who are not as well trained (California Commission on Peace Officer Standards and Training, 2009). Such training likely 
increases officers' awareness of the risks of on-duty driving and improves their driving-related activities, including seat belt use. ${ }^{i}$ Relatedly, the general traffic literature reveals that targeted and high-quality driver training is most likely to improve safe driving outcomes (Ball et al., 2010). As such, officers' perceived quality of academy and in-service driver training also may be associated with how seriously they take safe driving practices like seat belt use (Wolfe, McLean, Rojek, Alpert, \& Smith, 2020).

\section{Agency Policies}

Departmental regulations and policies may operate as important predictors of officer driving behavior. Hansen and colleagues (2015), for example, found that department policies regarding on-duty driving behaviors were significantly associated with less on-duty collision involvement. Importantly, however, they found that it was not the mere existence of a policy that mattered. The perceived likelihood of supervisors enforcing driving-related policies was predictive of collision involvement among individual officers. Specifically, officers who believed their supervisors likely would enforce departmental policies concerning on-duty speed were significantly less likely to have been involved in traffic crashes compared to their counterparts who did not believe they would be held accountable to such policies. In the same way, officers who perceive their supervisors as more likely to enforce their seat belt policy will report more frequent seat belt use. The perceived likelihood of enforcing other driving-related policies (e.g., concerning cellphone use, emergency driving, or pursuits) may also influence seat belt use.

\section{Organizational Characteristics}

Organizational factors are often key to explaining officer decision-making. Stop, arrest, and use of force behavior, for instance, is associated with external oversight stemming from highprofile incidents (e.g., consent decree; Alpert \& MacDonald, 2001; Chanin, 2015; Ingram et al., 
2014; Morgan \& Pally, 2016). Agencies under a consent decree for issues such as excessive use of force complaints sometimes witness depolicing among their officers (Alpert, McLean, \& Wolfe, 2017). Accordingly, we anticipate collision-related sentinel events to shape officer decisionmaking while driving on-duty. Working in an agency that recently had an officer killed or injured in a vehicle collision may increase the salience of driving safety to other officers and, all else equal, increase the frequency of seat belt use. Yet, as discussed above, officers often make behavioral decisions based on the risk of getting shot or assaulted by suspects. In this way, working in an agency that recently had one of its officers feloniously assaulted or killed may emphasize risks of the job in general, producing a greater safety consciousness that increases seat belt use. Or, the opposite relationship may emerge. Such experience may lead to less frequent seat belt use because officers fear being caught in their car during an ambush. Similar to our earlier argument, it is important to compare whether the experience of critical driving-related incidents has a stronger effect on seatbelt wearing behavior relative to more general experiences with the dangers of police work (e.g., a colleague being shot).

Beyond organizational experiences and sentinel events, organizational behavior research shows employees desire supervisors who treat them with distributive, procedural, interpersonal, and informational justice (Cohen-Charash \& Spector, 2001; Colquitt et al., 2001; Owens et al., 2018). ${ }^{\text {ii }}$ These four dimensions come together to form what is referred to as "organizational justice" (Colquitt, 2001). Officers that perceive organizational justice from their supervisors are more likely to comply with departmental policies and engage the public with democratic styles of policing (e.g., by using procedural justice and community-oriented policing), and less likely to rely on physical force to gain compliance (Bradford \& Quinton, 2014; Trinkner et al., 2016). 
Convincing officers to do what is best for themselves and the larger agency (i.e., to wear their seat belt) may be dictated by how much officers believe their agency and supervisors have their best interests in mind. Fair supervisory treatment—organizational justice-signals to subordinate officers that the department values them and that agency directives can be trusted (Wolfe \& Nix, 2017). Accordingly, we expect officers’ perceptions of organizational justice to be strongly tied to how frequently they wear a seat belt while driving on-duty.

\section{Methods}

\section{Data}

Data for this study come from a project funded by the Bureau of Justice Assistance (BJA) and supported by the California Commission on Peace Officer Standards and Training that involved a comprehensive examination of officer-involved traffic collisions in California. One component of the project, and the source of the data used in this study, involved surveying all patrol officers and immediate supervisors (sergeants and lieutenants) from eight small and midsized California police departments. ${ }^{\text {iii }}$ Members of the research team administered questionnaires in-person during roll calls at each of the agencies. To ensure adequate coverage of shifts, we administered surveys during various times of the day and week. The research team provided a brief overview of the study's purpose and underscored the voluntary nature of participation. Respondent officers were provided the questionnaires with a paid-postage envelope that could be returned when completed or mailed back to the research team. An online version of the questionnaire was made available to officers who preferred this mode of participation. A link to the survey was emailed to all patrol officers and supervisors in the eight partnering agencies. This technique has been used successfully in the past when attempting to achieve higher response rates and to capture officers that may have been absent on the day of survey administration. 
There were 696 patrol or immediate supervisor officers across the eight agencies we surveyed. Our protocol resulted in 478 returned surveys, but we removed 28 from the analysis because they were completed by people that were not full-time or sworn officers. Accordingly, our response rate was $64.7 \%$ which is slightly higher than the typical police officer survey according to recent research (Nix et al., 2017). Similar response pattern imputation was used to impute a small amount of missing values, which resulted in a total of 450 surveys for the analysis.

\section{Dependent Variables}

The dependent variable captured officers' frequency of seat belt use while driving on duty (“How often do you wear your seat belt while driving on duty?”). Responses were measured on a 5 -point scale $(1=$ never, 2 = rarely, $3=$ some of the time, $4=$ most of the time, and $5=$ all of the time). Two-thirds of respondents indicated they wear their seat belt "all of the time" (41.7\%) or "most of the time" (24.7\%). Of the remaining officers, 3.3\% indicated they never wear a seat belt while driving on duty, $13.6 \%$ said they wear it rarely, and $16.7 \%$ reported wearing a seat belt "some of the time.” Table 1 provides the descriptive statistics for all variables used in the analysis.

(Table 1 about here)

\section{Predictor Variables}

Officer characteristics. Consistent with the above theoretical framework, the first set of predictor variables examined in the analysis concerned officer characteristics. Four of these variables captured officers' demographics. Respondent gender was captured with a dummy variable $(1=$ male, $0=$ female $)$. Law enforcement experience was measured categorically to help protect respondents' anonymity ( $1=1-4$ years, $2=5-9$ years, $3=10-14$ years, $4=15-19$ years, 5 $=20-24$ years, and $6=25$ or more years). Officers' highest level of education was measured with an ordered-categorical variable ( 1 = high school, 2 = less than two years of college, 3 = associate's 
degree, 4 = bachelor's degree, and 5 = post-graduate degree). We also accounted for whether the respondent was a patrol officer with a dummy variable ( 1 = patrol officer, 0 = patrol supervisor). Lastly for this domain of predictors, we measured two informal social control-related variables. Respondents were asked to indicate whether they were currently in a committed relationship $(1=$ yes, $0=$ no) and whether they had children $(1=$ yes, $0=$ no $)$.

Officer safety risk perceptions. The next set of variables consisted of five measures that tapped into officers' perceptions of the safety risks associated with their job. Officers were asked to rate on a 6-point scale how likely ( 1 = very unlikely, 2 = unlikely, 3 = somewhat unlikely, $4=$ somewhat likely, 5 = likely, and 6 = very likely) it would be for them to be involved in a motor vehicle crash on-duty (risk of collision), assaulted on-duty (risk of assault), and shot while on-duty (risk of shot). Respondents also were asked to indicate their perceptions regarding the danger of emergency driving and danger of regular patrol driving $(1=$ not at all dangerous, $2=$ somewhat dangerous, 3 = dangerous, and 4 = very dangerous).

Risky driving attitudes and activity. A series of variables were used to capture officers' propensity for risky driving behavior. First, we constructed a risky driving attitude scale that was a mean index comprised of five survey items: "It is fun to drive fast while responding to a crime in-progress call”; "In general, officers must take risks to do their job well”; "Patrol officers must take more risks when responding to an officer assistance call than another type of coded call”; “Officers must take risks while driving patrol vehicles”; “If an officer doesn’t take risks they can’t be an effective police driver." Principal component analysis (PCA) showed the items loaded on a single component. Also, the items demonstrated adequate internal consistency $(\alpha=.75)$.

Next, officers were asked to indicate how often they use a cell while driving or text while driving on-duty. Each item was measured on the same 4-point scale $(1=$ regularly, $2=$ 
occasionally, 3 = rarely, and $4=$ never). Officers were asked whether they had ever been pulled over off-duty ( $1=$ yes, $0=$ no) driving a civilian car since becoming a police officer. Respondents were also asked how many off-duty (number of off-duty collisions) and on-duty (number of onduty collisions) vehicle collisions they had been involved in during the three years leading up to the survey. Each item was measured on a 3-point scale ( 0 = none, 1 = one, 2 = two or more).

Two scales were constructed that tapped into officers' cultural orientations toward the job that may influence their risk-taking while driving (Ingram et al., 2013). Aggressive enforcement orientation was a mean scale comprised of two items: "Enforcing the law is a patrol officer's most important responsibility” and "A good patrol officer is one who patrols aggressively by stopping cars, checking out people, running license checks, and so forth” $(r=.32)$. Order maintenance orientation was a five-item mean scale comprised of the following items: "How often do you think patrol officers should be expected to do something about neighbor disputes?”; "How frequently do you think patrol officers should be expected to do something about public nuisances (i.e. panhandling, drinking in public, loitering)?”; “How often do you think patrol officers should be expected to do something about nuisance businesses?”; “How often do you think patrol officers should be expected to do something about litter and trash?”; "How often would you say there are good reasons for not arresting someone who has committed a minor criminal offense?” ( 1 = very rarely, 2 = rarely, 3 = often, 4 = very often). The items demonstrated adequate internal consistency ( $\alpha=.66)$ and PCA revealed the items loaded on a single component.

Training experiences. Officers' were asked whether they had ever received any of the following driving-related training (each item was measured dichotomously; $1=$ yes, $0=$ no): driver decision training, track training, EVOC training, pursuit training, and simulator training. Beyond training experiences, respondents were also asked to indicate the quality of academy driving 
training and quality of in-service driving training they experienced. Each item was measured on a 6-point scale ( 1 = no related training, 2 = poor, 3 = below average, 4 = average, $5=$ good, and $6=$ excellent).

Agency policies. A series of questions addressed officers' perceptions regarding the likelihood that a supervisor would enforce driving-related policies. Each of the following variables was measured on the same 4 -point scale ( 1 = very unlikely, 2 = unlikely, $3=$ likely, and $4=$ very likely; officers that worked in an agency without such a policy were coded 1): supervisor enforce seat belt policy, supervisor enforce cellphone policy, supervisor enforce emergency driving policy, and supervisor enforce pursuit policy.

Organizational characteristics. The final domain of variables captured several organizational characteristics that may predict seat belt use. First, we constructed an organizational justice scale that was comprised of the following eight items: "In general, the approach of supervisors in my department tends to discourage me from giving extra effort” (reverse coded); "In general, supervisors in my department let officers know what is expected of them"; "In general, supervisors in my department are very interested in their subordinates"; "In general, supervisors in my department will support me when I am right even if it makes things difficult for them"; "When an officer does a particularly good job, top management will publicly recognize his or her performance"; "When an officer gets written up for a minor rule violation, he or she will be treated fairly by top management”; “Getting special assignments in the department depends on who you know, not on merit" (reverse coded); "The department leadership is very interested in the personal welfare of department employees.” All items were measured on the same 4-point scale ( 1 = strongly disagree, 2 = disagree, 3 = agree, and 4 = strongly agree), loaded on a single component, and demonstrated strong internal consistency $(\alpha=.86)$. Lastly, to gauge the 
potential salience of both recent driving-specific and general critical incidents in their agencies, respondents were asked whether any officer in their agency had been seriously hurt or killed in a car crash, by being struck by a car, by a gunshot, or by being assaulted in the three years prior to the survey (each item was measured dichotomously; $1=$ yes, $0=$ no).

\section{Analytic Strategy}

There are several strategies we considered for testing the relationships between each of the predictor variables and officers' reported frequency of seat belt use. One option would be to estimate a series of separate equations that explore the impact of variables from each of the theoretical domains. This would result in seven models (six for each of the domains and one fullysaturated model). We viewed this option as cumbersome and unnecessary. Our research question focuses on which factors predict seat belt use, all else equal. As such, we chose to estimate a single, fully-saturated model that regressed frequency of seat belt use on all the predictor variables. ${ }^{\text {iv }}$

Ordered logistic regression (hereafter, ologit) was used because the dependent variable was ordered categorical in nature. According to the Brant test, the proportional odds assumption was not violated in the analysis ( $\left.\operatorname{LR} \chi^{2}=105.00, p=0.481\right)$. All models used robust standard errors that adjusted for clustering within respondent agency.

\section{Results}

Table 2 presents the results of the ologit equation that examined the factors associated with frequency of seat belt use among respondent police officers $\left(\operatorname{LR} \chi^{2}=158.00\right.$; Pseudo $\left.R^{2}=0.126\right)$. We begin by focusing attention on the officer characteristics associated with seat belt use. Respondents' law enforcement experience was significantly and positively associated with seat belt use ( $b=.167, p=.005$ ). We calculated standardized effects to allow us to compare the magnitude of each predictor variables' relationship with seat belt use (\%StdX). Each standard 
deviation increase in experience corresponded with a $31 \%$ increase in officers' reported frequency of seat belt use (\%StdX = 30.7). Patrol officers' reported seat belt use was about $19 \%$ less frequent than their supervisor counterparts (\%StdX $=-19.0 ; b=-.466, p=.054)$. Contrary to expectations, female officers and those with more education did not report more frequent seat belt use than their counterparts. Likewise, being in a committed relationship and having children did not appear to invoke informal social control effects regarding seat belt use.

(Table 2 about here)

We now turn our attention to the "officer safety risk perceptions" domain of predictors. Only one of the variables had a marginally statistically significant relationship with seat belt use respondents' perceptions of the risk of a collision $(b=.135, p=.083)$. Every standard deviation increase in risk of collision corresponded with an $18 \%$ increase in the frequency of seat belt use (\%StdX $=17.5)$. On the other hand, officers' views of the risk of being assaulted or shot and their perceptions of the danger of regular patrol and emergency driving were not associated with the frequency of seat belt use.

Next, we consider whether officers that engage in riskier behaviors are less likely to wear a seat belt on duty. Our analysis found partial support for this argument. The risky driving attitude scale (e.g., believing it is fun to drive fast) was significantly and negatively associated with seat belt use ( $b=-.395, p=.005)$. A one standard deviation increase in this scale reduced the expected frequency of seat belt use by $29 \%(\% \operatorname{StdX}=29.2)$. Relatedly, officers that had been involved in at least one on-duty vehicle collision during the three years leading up to the survey reported wearing their seat belts $23 \%$ less frequently than their colleagues without an on-duty collision $(\% \operatorname{StdX}=-22.8 ; b=-.365, p<.001)$. Together, these results suggest that officers with psychological orientations favoring risky attitudes and those who exhibit riskier driving practices 
while on-duty wear a seat belt less frequently than their counterparts. It is necessary to point out that our analysis did not reveal a connection between the other measured risky driving behaviors and seat belt use. Also, police cultural orientations do not distinguish frequent from infrequent seat belt wearers.

Contrary to what many law enforcement practitioners and scholars may assume (including our own expectations), driver training experiences and quality perceptions were unrelated to seat belt use in our sample. This does not mean that training is irrelevant to motivating seat belt use. Rather, our results indicated that the types of driver training experienced by California officers in our sample was unrelated to their seat belt use.

Prior research shows that enforcement of agency driving-related policies can impact collision involvement among officers. Our analysis adds to this literature by revealing that officers more frequently wear their seat belts when they believe their supervisors will enforce agency seat belt policies ( $b=.690, p<.001)$. In fact, for every standard deviation increase on the questionnaire item, officers' frequency of seat belt use was expected to increase by over 98\% (\%StdX $=98.3)$. The perceived likelihood of supervisors enforcing cellphone use policies was related to seat belt use, but in the opposite direction than expected $(b=-.573, p=.005)$. Officers reported wearing a seat belt less frequently if they believed their supervisors were likely to enforce cellphone policies. In the next section, we will return to a discussion of why this relationship may have emerged.

This brings us to the final domain of predictor variables - organizational characteristics. Consistent with expectations, officers' evaluations of organizational justice within their agency were significantly and positively related to seat belt use $(b=.643, p=.011)$. A standard deviation increase in the scale increased the expected frequency of seat belt use by $42 \%(\% \operatorname{StdX}=41.6)$. Finally, officers who worked in an agency that recently had a colleague seriously hurt or killed 
after being struck by a car reported more frequent seat belt use $(b=.956, p=.041 ; \% \operatorname{StdX}=40.6)$.

Yet, having a colleague hurt or killed in a car crash was unrelated to the frequency of seat belt use. We will discuss the implications of these findings in more detail in the next section.

\section{Discussion}

Officer-involved traffic collisions are costly from a physical, emotional, and financial standpoint and are a common problem faced in policing. Accordingly, sustained efforts should be made to improve officer driving safety and decrease the chances of serious injuries and fatalities that stem from collision involvement. A leading factor of collision-related injuries and deaths among police officers is failure to wear a seat belt, which represents one of the most promising areas for improving officer driving safety. Our study first outlined the theoretical predictors of officer seat belt use. Next, we used a sample of officers from eight California police departments to explore the extent to which these factors were associated with reported seat belt use among our respondents. In this final section of the paper, we discuss the main predictors of seat belt use that were identified in the analysis and the implications the results have for police policy and practice and for the future study of officer-involved vehicle collisions.

Because the main purpose of this study was to identify the most important predictors of seat belt use, we are going to discuss each in order based on the magnitude of the relationship with frequency of seat belt use. Based on the standardized effect size estimates derived from our analysis, the following is a rank-order list of the correlates of seat belt use:

1. Supervisor likelihood of enforcing seat belt policy $(\% \operatorname{StdX}=98.3)$

2. Supervisor likelihood of enforcing cell phone policy $(\% \mathrm{StdX}=-43.2)$

3. Organizational justice $(\% \operatorname{StdX}=41.6)$

4. Colleague hurt/killed by being struck by car $(\% \operatorname{StdX}=40.6)$

5. Law enforcement experience $(\% \operatorname{StdX}=30.7)$

6. Risky driving attitude scale (\%StdX $=-29.2)$

7. Number of on-duty collisions (\%StdX $=-22.8)$

8. Patrol officer vs. supervisor ( $\% \operatorname{StdX}=-19.0$ ) 


\section{Risk of collision perception $(\% \operatorname{StdX}=17.5)$}

Perceived accountability of departmental policy regarding driving behaviors emerged as the strongest predictor of seat belt use. Police agencies must cultivate a culture where officers know they will be held accountable to such policies. Put simply, policy without accountability is a waste of time and will not increase officer safety. Officers who believe their supervisors will likely enforce policies concerning seat belt use are more inclined to wear their seat belts.

At the same time, however, there appears to be a collateral consequence of increasing the perceived likelihood of enforcing other driving-related policies such as cellphone use. We found officers that held this perception were significantly less likely to wear a seat belt. This finding could be explained by several mechanisms. Supervisors who are likely to enforce cellphone use policies may tend to focus exclusively on this issue (or, at least, be perceived to do so by their officers). Cellphone use being identified as a contributing factor in recent officer-involved collisions in some agencies may lead supervisors to behave in this way. Or, perhaps officers resent the enforcement of cellphone-related driving policies. Some officers may view such policies as unnecessary, performance hindering, or arbitrary. Such feelings would likely lead to a lack of commitment to other agency policies or directives like wearing a seat belt. Accordingly, drivingrelated policies are necessary to improve officer safety, but their creation and enforcement need to take two important issues into consideration: policies should not unnecessarily focus on a single issue (e.g., focus on cellphone use policies and ignore others) and supervisors should not engage in the arbitrary enforcement of such policies (e.g., be fair, consistent, and transparent).

This brings us to the next important predictor of officer seat belt use - organizational justice. Officers who feel their superiors treat them with respect, allow them to participate in agency decision-making, and distribute outcomes fairly across the department are more likely to 
trust the organization, buy-into departmental policies and goals, and partake in a wide-range of beneficial work outcomes. Our analysis showed that organizational justice can also increase officer driving safety by leading to more frequent seat belt use. Being treated fairly by superiors sends the message to line-level officers that the agency has its employees' best interests in mind. This leads officers to behave in manners consistent with policy, supervisor directives, and officer safety. Being transparent about policy creation and enforcement, explaining to officers why such actions are being taken, and soliciting line-level officer input during the process will go a long way in garnering officer commitment to more frequently wearing their seat belts. The importance of organizational justice should not go understated - behind having an accountable seat belt policy, organizational justice was the strongest predictor of seat belt use among officers in our sample. This is important from a practical standpoint because no new policies or technologies are necessarily required. Emphasizing fairness in policy creation, messaging, and enforcement will provide the most return on investment regarding increased officer seat belt use.

The next strongest predictor we identified of seat belt use was whether the respondent recently had an agency colleague hurt or killed after being struck by a car. This was a somewhat unexpected finding because we did not observe the same result regarding a colleague being hurt or killed in vehicle crash (which is more salient to the use of seat belts). Yet, it may be good news from an intervention standpoint. The finding may suggest that agencies can leverage such drivingrelated incidents that are not necessarily officer-involved crashes to highlight the importance of safe driving practices. In other words, police departments do not have to wait until an officer is hurt or killed in a crash to remind officers about the importance of buckling up. At the same time, we also observed that officers who believe the risk of a collision is high more frequently wear their seat belts while driving on-duty. Together, these findings suggest that agencies should partake in 
education campaigns that highlight the many driving-related dangers officers will face, the high probability of such dangers, and the consequences that stem from collisions. Discussing the risk of and actual experiences with driving-related officer injuries and deaths may help increase seat belt use. Continued educational campaigns may be necessary because the extent to which sentinel events lead to safer officer behavior may wane over time.

A recent analysis of a comprehensive collision reduction program implemented by the LVMPD found significant reduction in officer-involved collisions (Tiesman et al., 2019). As noted above, seat belt use among officers involved in collisions also increased following program implementation. The program involved changes to driving-related policy and accountability practices, an education campaign, and increased training. One of the limitations of the study was the inability to determine which of the program elements were more or less effective in these desired outcomes, an important consideration for implementation replication. The findings here suggest that accountability and education campaign components are critical elements to seat belt use.

Next, from the officer characteristic domain, law enforcement experience emerged as a significant predictor of seat belt use among respondent officers. Experience seems to make officers wiser or more realistic about the inherent dangers of not wearing a seat belt while driving on-duty. As part of the overall grant project that resulted in the collection of this survey data, we also conducted focus group interviews with patrol officers in each of the agencies. One of the most consistent themes that came from these discussions was that experience on the street was the most important predictor of risky driving-related behaviors (e.g., not wearing a seat belt). Officers were clear that this was not necessarily an age issue. Rather, maturity about the dangers of police driving comes with on-the-job experience more so than simply getting older. ${ }^{\mathrm{v}}$ 
From a practical standpoint, this suggests that even younger officers can be motivated to wear their seat belts if they have been on the job long enough to experience or hear about enough driving-related tragedies (involving both officers and civilians). This finding underscores the need for senior officers (in terms of years of service) to discuss driving experiences (both good and bad) with their less experienced and rookie colleagues. Such discussions can be both formal and informal and can help connect officers with driving-related risks on a personal or emotional level. Increasing the salience of such risks in the minds of officers may help change their attitudes and behaviors regarding seat belt use.

Finally, the risky driving attitude scale and on-duty collision experience seem to be good predictors of seat belt use. In this way, both attitudinal orientations about risky driving and actual risky driving behavior lower the frequency of seat belt use. Interventions should target risking driving attitudes when attempting to increase seat belt use. Additionally, our findings underscore the importance of detailed psychological and background screening tools during officer recruitment. Propensity for risk and previous civilian collision experience may be good assessments to filter out future dangerous driving behavior. Specifically regarding on-duty collision experience, such incidents are explained by a multitude of factors that are sometimes beyond officers' control (e.g., civilian negligence). However, on-duty collision experience, especially if frequent, may be a red-flag for overall risky driving behavior. This suggests that onduty collisions involvement may be used as part of an early warning system aimed at reducing problematic and dangerous officer behavior. Officers involved in collisions, regardless of how serious (i.e., even parking lot fender benders), may benefit from formal debriefings. Informal settings - sometimes referred to as "courageous conversations" - may also help communicate to officers their increased propensity for being involved in future collisions and the importance of 
buckling up. Indeed, the California Commission on Peace Officer Standards and Training has created online videos and learning portals to help agencies confront bad driving habits through mechanisms such as courageous conversations (see, https://post.ca.gov/did-you-knowconversations).

In the end, our study has helped move the literature forward regarding the theoretical reasons why police officers wear or do not wear their seat belts while driving on-duty. At the same time, however, our model left significant variation in seatbelt use unexplained. We encourage future researcher to uncover other factors that may play a role in predicting seatbelt use. With that said, these findings contribute to emerging programs and training initiatives focused officer safety issues resulting from collisions. In 2011, The Bureau of Justice Assistance (BJA) and Office of Community Oriented Policing Services created the national Officer Safety and Wellness group to identify and support efforts to improve officer safety, which has included attention to officerinvolved collisions (Stephens et al., 2013). The Destination Zero and Below 100 initiatives have made contributions to this focus through knowledge dissemination on officer-involved collisions, recognition of agency programs and training aids. Further, BJA through the VALOR Initiative, and more recently through the National Officer Safety Initiative (NOSI), have dedicated funding to the development of driving-related training programs to reduce collisions.

For these efforts we offer the following key take-away messages: (1) policy matters, but it must be enforced with fairness and officers must believe they will be held accountable to the policy, (2) education campaigns should communicate information about driving-related tragedies and focus on the inherent risk of collision-related injuries and deaths (senior officers can play a key role in such messaging), (3) oversight and early warning mechanisms of officers with risky driving attitudes and behaviors may pay dividends when trying to increase seat belt use among the 
most at-risk group of officers, and (4) fair managerial practices may increase seat belt use. We hope our study sparks more research on this important officer safety issue, and helps guide the development of stronger, more evidence-based interventions aimed at increasing seat belt use among police officers. 


\section{References}

Alpert, G. P. (1989). Police use of deadly force: The Miami experience. Critical issues in Policing, 480-496.

Alpert, G. P., \& MacDonald, J. M. (2001). Police use of force: An analysis of organizational characteristics. Justice quarterly, 18(2), 393-409.

Alpert, G. P., McLean, K., \& Wolfe, S. (2017). Consent decrees: An approach to police accountability and reform. Police Quarterly, 20(3), 239-249.

Alpert, G., \& Rojek, J. (2011). Frontline police officer assessments of risks and decision making during encounters with offenders. ARC Centre of Excellence in Policing and Security.

Ball, K., Edwards, J. D., Ross, L. A., \& McGwin Jr, G. (2010). Cognitive training decreases motor vehicle collision involvement of older drivers. Journal of the American Geriatrics Society, 58(11), 2107-2113.

Barker, J. C. (1999). Danger, duty, and disillusion: The worldview of Los Angeles police officers. Prospect Heights, IL: Waveland Press, Inc.

Blincoe, L. J., Seay, A. G, Zaloshnja, E., Miiler, T. R., Romano, E. O., Luchter, S. \& Spicer, R.S. (2002). The economic impact of motor vehicle crashes in 2000. Washington, D.C.: National Highway Traffic Safety Administration.

Bradford, B., \& Quinton, P. (2014). Self-legitimacy, police culture and support for democratic policing in an English constabulary. British Journal of Criminology, 54(6), 1023-1046.

California Commission on Peace Officer Standards and Training. (2009). Driver training study volume 1. West Sacramento, CA.

Chanin, J. M. (2015). Examining the sustainability of pattern or practice police misconduct reform. Police Quarterly, 18(2), 163-192.

Clarke, S., \& Robertson, I. (2005). A meta-analytic review of the Big Five personality factors and accident involvement in occupational and non-occupational settings. Journal of Occupational and Organizational Psychology, 78(3), 355-376.

Cohen-Charash, Y., \& Spector, P. E. (2001). The role of justice in organizations: A metaanalysis. Organizational Behavior and Human Decision Processes, 86(2), 278-321.

Colquitt, J. A. (2001). On the dimensionality of organizational justice: A construct validation of a measure. The Journal of Applied Psychology, 86(3), 386-400. 
Colquitt, J. A., Conlon, D. E., Wesson, M. J., Porter, C. O. L. H., \& Ng, K. Y. (2001). Justice at the millennium: A meta-analytic review of 25 years of organizational justice research. Journal of Applied Psychology, 86(3), 425-445.

Dahlen, E. R., Martin, R. C., Ragan, K., \& Kuhlman, M. M. (2005). Driving anger, sensation seeking, impulsiveness, and boredom proneness in the prediction of unsafe driving. Accident Analysis \& Prevention, 37(2), 341-348.

Destination Zero. (No Date). Retrieved January 17, 2020, from https://destinationzero.org/officer-traffic-safety/

De Winter, J. C. F., \& Dodou, D. (2010). The Driver Behaviour Questionnaire as a predictor of accidents: A meta-analysis. Journal of Safety Research, 41(6), 463-470.

Elander, J., West, R., \& French, D. (1993). Behavioral correlates of individual differences in road-traffic crash risk: An examination of methods and findings. Psychological Bulletin, 113(2), 279-294.

Ellwanger, S. J., \& Pratt, T. C. (2014). Self-control, negative affect, and young driver aggression: An assessment of competing theoretical claims. International Journal of Offender Therapy and Comparative Criminology, 58(1), 85-106.

Farmer, C. M., Klauer, S. G., McClafferty, J. A., \& Guo, F. (2015). Relationship of nearcrash/crash risk to time spent on a cell phone while driving. Traffic Injury Prevention, 16(8), 792-800.

Finn, P., \& Bragg, B. W. (1986). Perception of the risk of an accident by young and older drivers. Accident Analysis \& Prevention, 18(4), 289-298.

Garner, J. H., Maxwell, C. D., \& Heraux, C. G. (2002). Characteristics associated with the prevalence and severity of force used by the police. Justice Quarterly, 19(4), 705-746.

Gottfredson, M. R., \& Hirschi, T. (1990). A general theory of crime. Stanford, CA: Stanford University Press.

Hansen, J. A. (2015). Relationships between law enforcement officer-involved collisions and other police behaviors. (Doctoral dissertation). Retrieved from https://scholarcommons.sc.edu/cgi/viewcontent.cgi?article=4706\&context=etd.

Hansen, J. A., Rojek, J., Wolfe, S. E., \& Alpert, G. P. (2015). The influence of department policy and accountability on officer-involved collisions. Policing: An International Journal of Police Strategies \& Management, 38, 578-594.

Hirschi, T., \& Gottfredson, M. (1993). Commentary: Testing the general theory of crime. Journal of Research in Crime and Delinquency, 30(1), 47-54. 
Ingram, J. R., Paoline, E. A., \& Terrill, W. (2013). A multilevel framework for understanding police culture: The role of the workgroup. Criminology, 51(2), 365-397.

Ingram, J. R., Terrill, W., \& Paoline, E. A. (2018). Police culture and officer behavior: Application of a multilevel framework. Criminology, 56(4), 780-811.

Ingram, J. R., Weidner, R. R., Eugene III, A. P., \& Terrill, W. (2014). Supervisory influences on officers' perceptions of less lethal force policy: a multilevel analysis. Policing: An International Journal of Police Strategies and Management, 37(2), 355-372.

James, S. M. (2015). Distracted driving impairs police patrol officer driving performance. Policing: An International Journal of Police Strategies \& Management, 38, 505-516.

James, S. M., \& Vila, B. (2015). Police drowsy driving: Predicting fatigue-related performance decay. Policing: An International Journal of Police Strategies \& Management, 38(3), 517538.

Klauer, S. G., Guo, F., Simons-Morton, B. G., Ouimet, M. C., Lee, S. E., \& Dingus, T. A. (2014). Distracted driving and risk of road crashes among novice and experienced drivers. New England Journal of Medicine, 370(1), 54-59.

Langham, M., Hole, G., Edwards, J., \& O'Neil, C. (2002). An analysis of 'looked but failed to see' accidents involving parked police vehicles. Ergonomics, 45, 167-185.

LaTourette, T. (2015). Risk factors for injury in law enforcement office vehicle crashes. Policing: An International Journal of Police Strategies \& Management, 38(3), 478-504.

Laub, J.H., \& Sampson, R. J. (2009). Shared beginnings, divergent lives. Cambridge, MA: Harvard University Press.

Lauritsen, J. L., Heimer, K., \& Lynch, J. P. (2009). Trends in the gender gap in violent offending: New evidence from the National Crime Victimization Survey. Criminology, 47(2), 361399.

Lee, H., Vaughn, M. S., \& Lim, H. (2014). The impact of neighborhood crime levels on police use of force: An examination at micro and meso levels. Journal of Criminal Justice, 42(6), 491-499.

Lewis, I., Watson, B., \& Tay, R. (2007). Examining the effectiveness of physical threats in road safety advertising: The role of the third-person effect, gender, and age. Transportation Research Part F: Traffic Psychology and Behaviour, 10(1), 48-60.

Lund, I. O., \& Rundmo, T. (2009). Cross-cultural comparisons of traffic safety, risk perception, attitudes and behaviour. Safety Science, 47(4), 547-553. 
Malouf, E. T., Schaefer, K. E., Witt, E. A., Moore, K. E., Stuewig, J., \& Tangney, J. P. (2014). The brief self-control scale predicts jail inmates' recidivism, substance dependence, and post-release adjustment. Personality and Social Psychology Bulletin, 40(3), 334-347.

Mayhew, D. R., \& Simpson, H. M. (2002). The safety value of driver education and training. Injury Prevention, 8(suppl 2), ii3-ii8.

McCluskey, J. D., \& Terrill, W. (2005). Departmental and citizen complaints as predictors of police coercion. Policing: An International Journal of Police Strategies \& Management, 28(3), 513-529.

Morgan, S. L., \& Pally, J. A. (2016). Ferguson, Gray, and Davis: An analysis of recorded crime incidents and arrests in Baltimore City, March 2010 through December 2015. A report written for the 21st Century Cities Initiative at Johns Hopkins University. (Retrieved from) http://socweb.soc.jhu.edu/faculty/morgan/papers/ MorganPally2016.pdf.

National Center for Statistics and Analysis (NCSA). (2019, June). Seat Belt Use in 2018-Use Rates in the States and Territories (Traffic Safety Facts Crash Stats. Report No. DOT HS 812 763). Washington, DC: National Highway Traffic Safety Administration

National Law Enforcement Officer Memorial Fund. (No Date). Retrieved August 28, 2019, from https://nleomf.org/facts-figures/causes-of-law-enforcement-deaths.

Newnam, S., Griffin, M. A., \& Mason, C. (2008). Safety in work vehicles: a multilevel study linking safety values and individual predictors to work-related driving crashes. Journal of Applied Psychology, 93(3), 632.

Newnam S., Watson B. and Murray W. (2002). A comparison of the factors influencing the safety of workrelated drivers in work and personal vehicles. Proceedings of the 2002 Road Safety Research, Policing and Education Conference. (pp.488-495). Adelaide: Transport SA.

Newnam, S., Watson, B., \& Murray, W. (2004). Factors predicting intentions to speed in a work and personal vehicle. Transportation Research Part F: Traffic Psychology and Behaviour, 7(4-5), 287-300.

Nix, J., Pickett, J. T., Baek, H., \& Alpert, G. P. (2017). Police research, officer surveys, and response rates. Policing and Society, 1-21.

Nix, J., Pickett, J. T., Wolfe, S. E., \& Campbell, B. A. (2017). Demeanor, race, and police perceptions of procedural justice: Evidence from two randomized experiments. Justice Quarterly, 34(7), 1154-1183.

Noh, E. Y. (2011). Characteristics of law enforcement officer's fatalities in motor vehicle crashes. Washington D.C.: National Highway Traffic Safety Administration. 
Nordfjærn, T., Jørgensen, S., \& Rundmo, T. (2011). A cross-cultural comparison of road traffic risk perceptions, attitudes towards traffic safety and driver behaviour. Journal of Risk Research, 14(6), 657-684.

Oron-Gilad, T., Szalma, J. L., Stafford, S. C., \& Hancock, P. A. (2005). Police officers seat belt use while on duty. Transportation Research Part F: Traffic Psychology and Behaviour, 8(1), 1-18.

Owens, E., Weisburd, D., Amendola, K., \&Alpert, G. (2018). Can you build a better cop? Experimental evidence on supervision, training, and policing in the community. Criminology and Public Policy, 17, 41-87.

Paoline, E. A. (2003). Taking stock: Toward a richer understanding of police culture. Journal of Criminal Justice, 31(3), 199-214.

Parker, D., West, R., Stradling, S., \& Manstead, A. S. (1995). Behavioural characteristics and involvement in different types of traffic accident. Accident Analysis \& Prevention, 27(4), 571-581.

Pickett, J., \& Nix, J. (2019). Demeanor and police culture: Theorizing how civilian cooperation influences police officers. Policing: An International Journal.

Pratt, T. C., \& Cullen, F. T. (2000). The empirical status of Gottfredson and Hirschi's general theory of crime: A meta-analysis. Criminology, 38(3), 931-964.

Pratt, T. C., Turanovic, J. J., Fox, K. A., \& Wright, K. A. (2014). Self-control and victimization: A meta-analysis. Criminology, 52(1), 87-116.

Redelmeier, D. A., \& Tibshirani, R. J. (1997). Association between cellular-telephone calls and motor vehicle collisions. New England Journal of Medicine, 336(7), 453-458.

Reisig, M. D., Wolfe, S. E., \& Pratt, T. C. (2012). Low self-control and the religiosity-crime relationship. Criminal Justice and Behavior, 39(9), 1172-1191.

Romano, E. O., Tippetts, A. S., \& Voas, R. B. (2006). Language, income, education, and alcoholrelated fatal motor vehicle crashes. Journal of ethnicity in substance abuse, 5(2), 119-137.

Sampson, R. J., \& Laub, J. H. (1995). Crime in the making: Pathways and turning points through life. Cambridge, MA: Harvard University Press.

Sherman, L. W., \& Blumberg, M. (1981). Higher education and police use of deadly force. Journal of Criminal Justice, 9(4), 317-331.

Shjarback, J. (2018). "Neighborhood" influence on police use of force: state-of-the-art review. Policing: An International Journal, 41(6), 859-872. 
Smith, D. A. (1986). The neighborhood context of police behavior. In A. J. Reiss Jr. \& M. Tonry (Eds.), Crime and Justice: Vol. 8. Communities and crime. Chicago, IL: University of Chicago Press.

Stawinski, H.P. (2014). Buckle up, slow down, pay attention. Arrive Alive. Highway Safety Initiatives. The Police Chief, (81) October: 122-123.

Stephens, D. Fielder, M. L. \& Edwards, S. M. (2013). OSW Group Meeting Summary: Vehicle Operation, Risk Management, and Problem-Based Learning, April 25, 2012. Washington, D.C.: Office of Community Oriented Policing Services.

Sümer, N. (2003). Personality and behavioral predictors of traffic accidents: testing a contextual mediated model. Accident Analysis \& Prevention, 35(6), 949-964.

Tangney, J. P., Baumeister, R. F., \& Boone, A. L. (2004). High self-control predicts good adjustment, less pathology, better grades, and interpersonal success. Journal of Personality, 72(2), 271-324.

Tay, R. (2002). Exploring the effects of a road safety advertising campaign on the perceptions and intentions of the target and non-target audiences to drink and drive. Traffic Injury Prevention, 3, 195-200.

Tay, R. (2005). The Effectiveness of Enforcement and Publicity Campaigns on Serious Crashes Involving Young Male Drivers: Are Drink Driving and Speeding Similar? Accident Analysis and Prevention, 37(5), 922-929.

Terrill, W., Paoline, E. A., \& Manning, P. K. (2003). Police culture and coercion. Criminology, 41(4), 1003-1034.

Terrill, W., \& Reisig, M. D. (2003). Neighborhood context and police use of force. Journal of Research in Crime and Delinquency, 40(3), 291-321.

Tiesman, H. M., \& Heick, R. J. (2014). Law enforcement officer motor vehicle safety: Findings from a statewide survey (No. 2015-101). Cincinnati, OH: U.S. Department of Health and Human Services, Centers for Disease Control and Prevention, National Institute for Occupational Safety and Health, DHHS (NIOSH).

Tiesman, H. M., Gwilliam, M., Rojek, J., Hendricks, S., Montgomery, B., \& Alpert, G. (2019). The impact of a crash prevention program in a large law enforcement agency. American Journal of Industrial Medicine, 62(10), 847-858.

Tiesman, H. M., Rojek, J., Gwilliam, M., \& Alpert, G. (2016). Evaluation of a motor-vehicle crash prevention program in law enforcement. Presentation at the annual meeting of the International Association of Chiefs of Police, San Diego, CA. 
Toby, J. (1957). Social disorganization and stake in conformity: Complementary factors in the predatory behavior of hoodlums. Journal of Criminal Law, Criminology and Police Science, 48(1), 12-17.

Trinkner, R., Tyler, T. R., \& Goff, P. A. (2016). Justice from within: The relations between a procedurally just organizational climate and police organizational efficiency, endorsement of democratic policing, and officer well-being. Psychology, Public Policy, and Law, 22(2), 158-172.

Ulleberg, P., \& Rundmo, T. (2003). Personality, attitudes and risk perception as predictors of risky driving behaviour among young drivers. Safety Science, 41(5), 427-443.

Vila, B. (2006). Impact of long work hours on police officers and the communities they serve. American Journal of Industrial Medicine, 49(11), 972-980.

Vila, B. (2009). Sleep deprivation: What does it mean for public safety officers. NIJ Journal, 262, 26-31.

Wehr, K. (2015). Agency culture and banality of risk. Policing: An International Journal of Police Strategies \& Management, 38(3), 539-562.

Wehr, K., Alpert, G., \& Rojek, J. (2012). The fear of the ninja assassin: understanding the role of agency culture in injurious and fatal on-duty vehicle collisions. Journal of California Law Enforcement, 46(2), 25-31.

Weisburd, D., Greenspan, R., Hamilton, E. E., Williams, H., \& Bryant, K. A. (2000). Police attitudes toward abuse of authority: Findings from a national study. Washington, D.C.: US Department of Justice, Office of Justice Programs, National Institute of Justice.

Wilson, M., \& Daly, M. (1985). Competitiveness, risk taking, and violence: The young male syndrome. Ethology and Sociobiology, 6(1), 59-73.

Wolfe, S. E., \& Hoffmann, J. P. (2016). On the measurement of low self-control in Add Health and NLSY79. Psychology, Crime \& Law, 22(7), 619-650.

Wolfe, S. E., \& Nix, J. (2017). Police officers' trust in their agency: Does self-legitimacy protect against supervisor procedural injustice? Criminal Justice and Behavior, 44(5), 717-732.

Wolfe, S. E., \& Piquero, A. R. (2011). Organizational justice and police misconduct. Criminal Justice and Behavior, 38(4), 332-353.

Wolfe, S. E., Rojek, J., Alpert, G., Tiesman, H., \& James, S. (2015). Characteristics of officerinvolved vehicle collisions in California. Policing: An International Journal of Police Strategies \& Management, 38(3), 458-477. 
Wolfe, S. E., McLean, K., Rojek, J., Alpert, G. P., \& Smith, M. R. (2020). Advancing a Theory of Police Officer Training Motivation and Receptivity. Justice Quarterly, DOI: 10.1080/07418825.2019.1703027.

Wolfe, S., Rojek, J., McLean, K., \& Alpert, G. (2020). Social Interaction Training to Reduce Police Use of Force. The ANNALS of the American Academy of Political and Social Science, 687. 
Table 1

Descriptive statistics for variables used in the multivariate analysis

\begin{tabular}{lcccc}
\hline & Mean/\% & S.D. & Min & Max \\
\hline Dependent variable & & & 1 & 5 \\
$\quad$ Frequency of seat belt use & 3.88 & 1.19 & & 1 \\
Officer Characteristics & & & 0 & 6 \\
Male & $86.0 \%$ & -- & 1 & 5 \\
Law enforcement experience & 3.35 & 1.60 & 1 & 1 \\
Education & 3.29 & 1.03 & 0 & 1 \\
Patrol officer & $71.6 \%$ & -- & 0 & 1 \\
Committed relationship & $85.1 \%$ & -- & 0 & -
\end{tabular}

\section{Officer Safety Risk Perceptions}

Risk of collision

Risk of being assaulted

Risk of being shot

Danger of emergency driving

Danger of regular patrol driving

\section{Risky Driving Attitudes and Activity}

Risky driving attitude scale

Use a cell while driving

Text while driving

Pulled over off duty

Number of off-duty collisions

Number of on-duty collisions

Aggressive enforcement orientation

Order maintenance orientation

Training Experiences

Driver decision training

Track training

EVOC training

Pursuit training

Simulator training

Quality of academy driving training

Quality of in-service driving training

\section{Agency Policies}

Supervisor enforce seat belt policy

Supervisor enforce cellphone policy

Supervisor enforce emergency driving

policy

Supervisor enforce pursuit policy

\section{Organizational Characteristics}

Organizational justice

Agency officer hurt or killed in car crash

Agency officer hurt or killed by being

struck by car

Agency officer hurt or killed by gunshot

Agency officer hurt or killed by being assaulted
4.58

$\begin{array}{lr}4.58 & 1.19 \\ 4.64 & 1.27 \\ 3.38 & 1.26 \\ 3.16 & .79 \\ 2.02 & .62\end{array}$

3.22

2.65

3.17

$87.1 \%$

.30

.47

2.98

2.74

6

6

6

4

4

5

4

4

1

2

2

4

4

$85.1 \% \quad---\quad 0 \quad 1$

$69.8 \%$

$95.6 \%$

$92.2 \%$

$74.7 \%$

4.27

3.91

2.49

2.39

3.39

3.53

2.77

$46.4 \%$

$--$

$---$

$--$

$--$

.89

1.08

.99

.99

.78

.77

.54

$---$

$\begin{array}{ll}-- & 0\end{array}$

$14.9 \%$

$--\quad 0$

1

1

1

$22.9 \%$

$14.7 \%$

$---$
4

1

1

1

1

5

5

4

4

4

4

1

1

1

1 
Table 2. Predictors of seat belt use among police officers $(\mathrm{N}=450)$

\begin{tabular}{|c|c|c|c|}
\hline \multirow[t]{2}{*}{ Variables: } & \multicolumn{3}{|c|}{ Frequency of seat belt use ${ }^{\mathrm{a}}$} \\
\hline & Estimate & Robust SE & $\% \operatorname{StdX}$ \\
\hline \multicolumn{4}{|l|}{ Officer Characteristics } \\
\hline Male & -.493 & .362 & -- \\
\hline Law enforcement experience & $.167 * *$ & .060 & 30.7 \\
\hline Education & -.026 & .116 & -- \\
\hline Patrol officer & $-.466 \dagger$ & .242 & -19.0 \\
\hline Committed relationship & .441 & .358 & -- \\
\hline Children & -.088 & .211 & -- \\
\hline \multicolumn{4}{|l|}{ Officer Safety Risk Perceptions } \\
\hline Risk of collision & $.135 \dagger$ & .078 & 17.5 \\
\hline Risk of being assaulted & -.076 & .125 & -- \\
\hline Risk of being shot & .124 & .106 & -- \\
\hline Danger of emergency driving & .059 & .120 & -- \\
\hline Danger of regular patrol driving & .223 & .187 & -- \\
\hline \multicolumn{4}{|l|}{ Risky Driving Attitudes and Activity } \\
\hline Risky driving attitude scale & $-.395^{* *}$ & .141 & -29.2 \\
\hline Use a cell while driving & .007 & .204 & -- \\
\hline Text while driving & .014 & .289 & -- \\
\hline Pulled over off duty & -.272 & .264 & -- \\
\hline Number of off-duty collisions & -.246 & .169 & -- \\
\hline Number of on-duty collisions & $-.365^{* *}$ & .091 & -22.8 \\
\hline Aggressive enforcement orientation & -.431 & .292 & -- \\
\hline Order maintenance orientation & .015 & .348 & -- \\
\hline \multicolumn{4}{|l|}{ Training Experiences } \\
\hline Driver decision training & -.118 & .139 & -- \\
\hline Track training & .275 & .251 & -- \\
\hline EVOC training & -.748 & .581 & -- \\
\hline Pursuit training & -.298 & .292 & -- \\
\hline Simulator training & -.485 & .387 & -- \\
\hline Quality of academy driving training & -.048 & .131 & -- \\
\hline Quality of in-service driving training & .143 & .133 & -- \\
\hline \multicolumn{4}{|l|}{ Agency Policies } \\
\hline Supervisor enforce seat belt policy & $.690 * *$ & .151 & 98.3 \\
\hline Supervisor enforce cellphone use policy & $-.573 * *$ & .204 & -43.2 \\
\hline Supervisor enforce emergency driving policy & .154 & .248 & -- \\
\hline Supervisor enforce pursuit policy & -.176 & .430 & -- \\
\hline \multicolumn{4}{|l|}{ Organizational Characteristics } \\
\hline Organizational justice & $.643 *$ & .253 & 41.6 \\
\hline Agency officer hurt or killed in car crash & -.107 & .234 & -- \\
\hline Agency officer hurt or killed by being struck by car & $.956^{*}$ & .469 & 40.6 \\
\hline Agency officer hurt or killed by gunshot & -.050 & .287 & -- \\
\hline Agency officer hurt or killed by being assaulted & -.248 & .237 & -- \\
\hline Pseudo $R^{2}=$ & & .126 & \\
\hline
\end{tabular}

${ }^{\text {a }}$ Ordered logistic regression equation.

${ }^{* *} p<.01 ;{ }^{*} p<.05 ; \dagger p<.10$ (two-tailed test). 
${ }^{\mathrm{i}}$ While we expect more driver training to increase seat belt, it is important to point out that among the general public there is mixed evidence concerning whether driver education increases driving safety (Mayhew \& Simpson, 2003). ${ }^{i i}$ Distributive fairness deals with how fairly supervisors distribute outcomes (e.g., promotions, reprimands) throughout the organization. Procedural justice refers to the fairness of processes used by supervisors. Employees want to experience consistency and impartiality in decision-making and be provided a voice by supervisors. Interpersonal justice refers to how respectfully supervisors treat employees. And, finally, informational justice concerns the degree to which supervisors are transparent with employees and provide clear explanations for decisions.

iii The average number of patrol officers and immediate supervisors in the surveyed agencies was 87 . The agencies ranged from 41 to 145 officers at the time of survey administration.

iv Given the number of predictor variables in the model presented in Table 2, we ran the risk of not having sufficient power to identify weak associations with seat belt use. Accordingly, we conducted a sensitivity analysis that involved us estimating a separate ordered logistic regression equation for each of the groups of predictor variables (six in total), net of officer characteristics. The results from each of the models were substantively identical to those presented in Table 2. Only one difference emerged. In the equation for the "Officer Safety Risk Perceptions" variables, risk of being shot emerged as statistically significant. No other variables in any of the equations switched from non-significance to significance, or vice versa. Accordingly, lack power or oversaturation are not a problem within our analysis. We thank an anonymous reviewer for suggesting this sensitivity analysis.

${ }^{v}$ This finding may also help explain why we observed patrol officers being less likely to wear a seat belt than their patrol supervisors. Yet, this could be the result of a selection effect - good decision makers are promoted to supervisory positions. 